\title{
Investigation and hazard assessment of the 2003 and 2007 Staircase Falls rock falls, Yosemite National Park, California, USA
}

\author{
G. F. Wieczorek ${ }^{1}$, G. M. Stock ${ }^{2}$, P. Reichenbach ${ }^{3}$, J. B. Snyder ${ }^{4}$, J. W. Borchers ${ }^{5}$, and J. W. Godt ${ }^{6}$ \\ ${ }^{1}$ US Geological Survey, MS926A, Reston, Virginia, USA \\ ${ }^{2}$ Division of Resources Management and Science, Yosemite National Park, El Portal, California, USA \\ ${ }^{3}$ CNR-IRPI, via della Madonna Alta, 126, 06128 Perugia, Italy \\ ${ }^{4}$ Yosemite National Park (retired), Davis, California, USA \\ ${ }^{5}$ US Geological Survey (retired), Sacramento, California, USA \\ ${ }^{6}$ US Geological Survey, MS966, Denver, Colorado, USA
}

Received: 31 January 2008 - Revised: 23 April 2008 - Accepted: 23 April 2008 - Published: 6 May 2008

\begin{abstract}
Since 1857 more than 600 rock falls, rock slides, debris slides, and debris flows have been documented in Yosemite National Park, with rock falls in Yosemite Valley representing the majority of the events. On 26 December 2003, a rock fall originating from west of Glacier Point sent approximately $200 \mathrm{~m}^{3}$ of rock debris down a series of jointcontrolled ledges to the floor of Yosemite Valley. The debris impacted talus near the base of Staircase Falls, producing fragments of flying rock that struck occupied cabins in Curry Village. Several years later on 9 June 2007, and again on 26 July 2007, smaller rock falls originated from the same source area. The 26 December 2003 event coincided with a severe winter storm and was likely triggered by precipitation and/or frost wedging, but the 9 June and 26 July 2007 events lack recognizable triggering mechanisms. We investigated the geologic and hydrologic factors contributing to the Staircase Falls rock falls, including bedrock lithology, weathering, joint spacing and orientations, and hydrologic processes affecting slope stability. We improved upon previous geomorphic assessment of rock-fall hazards, based on a shadow angle approach, by using STONE, a three-dimensional rockfall simulation computer program. STONE produced simulated rock-fall runout patterns similar to the mapped extent of the 2003 and 2007 events, allowing us to simulate potential future rock falls from the Staircase Falls detachment area. Observations of recent rock falls, mapping of rock debris, and simulations of rock fall runouts beneath the Staircase
\end{abstract}

Correspondence to: G. M. Stock (greg_stock@nps.gov)
Falls detachment area suggest that rock-fall hazard zones extend farther downslope than the extent previously defined by mapped surface talus deposits.

\section{Introduction}

Yosemite Valley is a $\sim 1 \mathrm{~km}$ deep, glacially carved canyon in granite located in the central Sierra Nevada, California. Since 1857 , various types of landslides, particularly rock falls, rock slides, debris slides, and debris flows, have been recognized in Yosemite Valley. Prior to 1916, landslides were sporadically documented by observant visitors, including Josiah Whitney, the first State Geologist of California; James Hutchings, author and hotel owner in Yosemite; John Muir, noted naturalist; and Joseph LeConte, Professor of Geology at the University of California. More systematic recording of landslides, primarily those affecting facilities, began after 1916 in the monthly National Park Service (NPS) Superintendent's reports. Following the 1980 Mammoth Lakes earthquakes, which triggered nine rock falls and rock slides in Yosemite Valley, the US Geological Survey (USGS) and the NPS began to collect reports of historic rock falls and to examine and document new rock falls (e.g., Wieczorek et al., 1992; Wieczorek and Snyder, 1999; Wieczorek et al., 2000; Wieczorek and Snyder, 2004). Between 1857 and 2007, more than 600 landslides have been documented in Yosemite National Park, with the vast majority of events occurring as rock falls and rock slides in Yosemite Valley (Wieczorek and Snyder, 2004, and unpublished data). Observed rock falls and rock slides range in size from $<1 \mathrm{~m}^{3}$

Published by Copernicus Publications on behalf of the European Geosciences Union. 


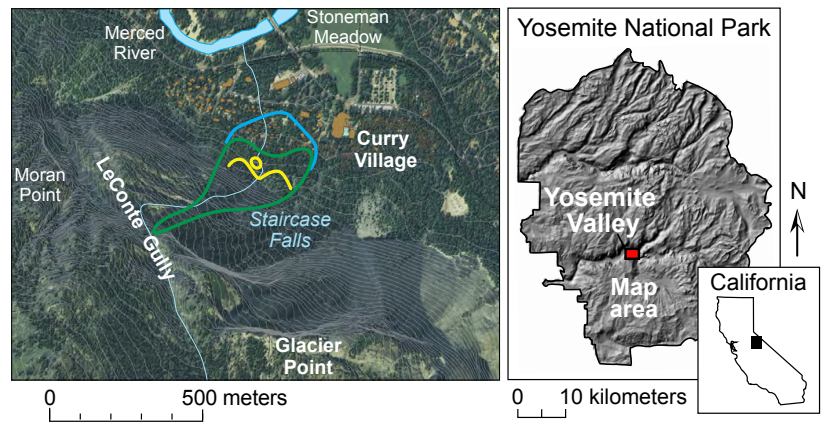

Fig. 1. Map of Glacier Point area in Yosemite Valley, California showing 26 December 2003 Staircase Falls rock fall into Curry Village. Green lines show initial detachment area, travel path, and limit of rock debris; yellow lines delimit areas where trees were knocked down; blue lines show limit of flyrock. Contour interval is $20 \mathrm{~m}$. Inset shows location of Yosemite Valley in Yosemite National Park, California.

to as much as $\sim 600000 \mathrm{~m}^{3}$ (Wieczorek and Snyder, 2004). Since 1857, 14 people have been killed and at least 62 injured by landslides in Yosemite.

Some landslides in Yosemite Valley have been observed during rainstorms, earthquakes, or in association with other natural triggering events (Wieczorek and Snyder, 2004). However, most landslides were not directly observed when they occurred and many of their triggers are unknown. For example, although infiltrating rainfall has not literally been observed filling bedrock joints, time coincidence of storms and rock falls suggest that increased groundwater pressure may be one factor in destabilizing jointed rock masses. In many cases, even though rock falls and rock slides were closely observed, no specific triggering mechanisms were recognized. For example, on 6 August 1870 Joseph LeConte observed a very large rock fall from Glacier Point in eastern Yosemite Valley, but did not note a concurrent storm or earthquake (LeConte, 1875). During the period 1857$2006,55 \%$ of documented landslides had unreported or unrecognized triggers (Wieczorek and Snyder, 2004, and unpublished data). Through detailed study of individual landslide events (Wieczorek and Snyder, 1999; Wieczorek et al., 2000), compilation and analysis of an historic landslide database (Wieczorek et al. 1992; Wieczorek and Jäger, 1996; Wieczorek and Snyder, 2004), geologic mapping (Wieczorek et al., 1998, 1999), and numerical modeling (Guzzetti et al., 2003), geologists have achieved a better scientific understanding of landslide triggering mechanisms and causative factors in Yosemite, and of the associated hazard and risk.

In the vicinity of Glacier Point (Figs. 1, 2), at least 70 rock falls, rock slides and debris flows have been recorded between 1870 and 2007 (Wieczorek and Snyder, 2004, and unpublished data). On 26 December 2003, a rock fall originated from the Staircase Falls area below Glacier Point and in the vicinity of Curry Village (Fig. 1; Wieczorek and Sny-

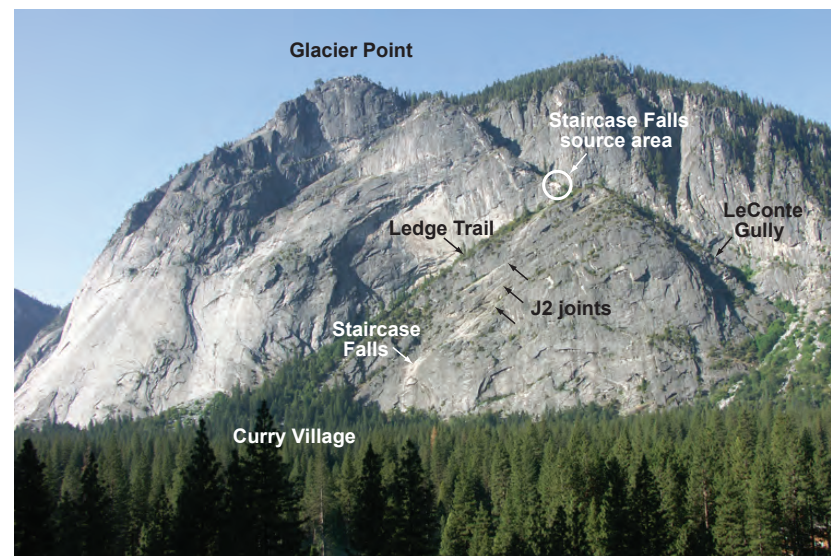

Fig. 2. Western portion of Glacier Point showing Staircase Falls rock-fall detachment area (circled) and path of Staircase Falls and abandoned Ledge Trail along eastward dipping J2 joint sets (see Table 1 for joint orientation data). Cliff faces exhibit influence of vertical regional joints weathered back along $\mathrm{J} 1$ exfoliation joints, which are present on nearly all visible rock surfaces.

der, 2004). Subsequent smaller rock falls from the same detachment area occurred in June and July of 2007. We conducted detailed investigations of these rock falls in order to 1) accurately map the distribution of rock debris at the base of the cliff, 2) assess the stability of the detachment area, 3) identify, if possible, the mechanism(s) that triggered the rock falls, 4) evaluate the geologic and hydrologic conditions that contributed to failure, and 5) assess future rock fall hazard from the Staircase Falls rock-fall detachment area using three-dimensional rock-fall simulations. This work furthers the ongoing study of geologic hazards in Yosemite Valley (e.g., Wieczorek et al., 1992; Wieczorek and Jäger, 1996; Wieczorek and Snyder, 1999; Wieczorek et al., 1998, 1999; Wieczorek et al., 2000; Wieczorek and Snyder, 2004; Guzzetti et al., 2003; Bertolo and Wieczorek, 2005).

\section{Staircase Falls rock-fall detachment area}

The Staircase Falls rock-fall detachment area is below and west of Glacier Point, on the eastern edge of LeConte Gully and immediately above Staircase Falls (Figs. 1,2). The detachment area is at an elevation of $1770 \mathrm{~m}, 555 \mathrm{~m}$ above the floor of Yosemite Valley. Prior to 2003, there were no documented observations of historic rock fall activity from this detachment area, but accumulations of rock debris and a lack of trees on a prominent ledge $\sim 20 \mathrm{~m}$ below the detachment area suggest earlier (pre-1850) rock-fall activity from the site. The active rock-fall detachment surface is on the upper northeast side of a jointed, weathered bedrock fin that projects out $\sim 28 \mathrm{~m}$ to the northwest from the eastern edge of LeConte Gully (Fig. 3). Here, Staircase Creek, which originates on the rim of Yosemite Valley near Glacier Point, turns 


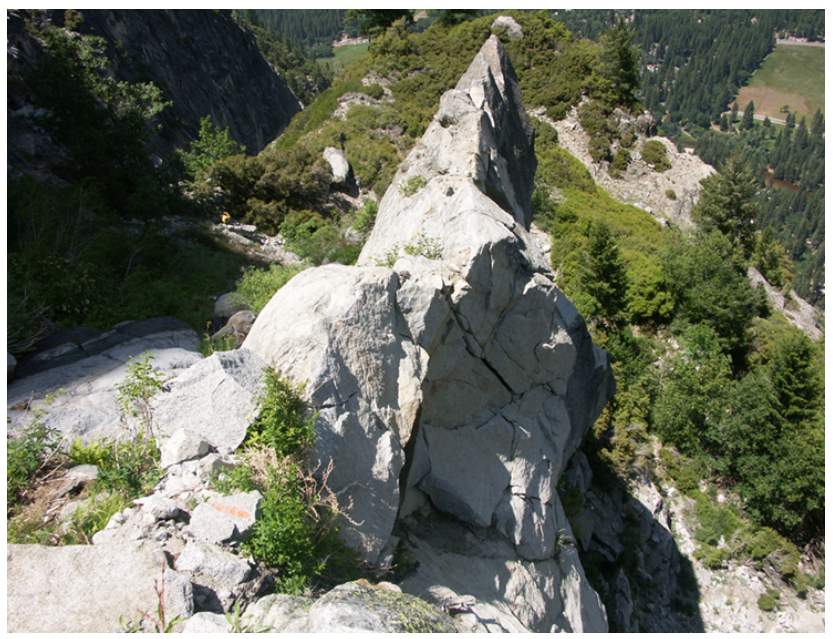

Fig. 3. Staircase Falls rock-fall detachment area, showing narrow projecting bedrock fin. 2003 and 2007 rock falls occurred from center-right side of fin. Floor of Yosemite Valley $555 \mathrm{~m}$ below is in upper right of photograph. Staircase Creek flows down left (southwest) side of fin before turning sharply right (northeast) around the base of fin to top of Staircase Falls.

sharply out of LeConte Gully and flows around the bedrock fin to reach the top of Staircase Falls (Figs. 2, 3).

\section{Staircase Falls rock falls}

\subsection{December 2003 rock fall}

The 2003 and 2007 events originating from the Staircase Falls detachment area were rock falls according to the classification system of Varnes (1978). The first and largest rock fall occurred at 00:45 Pacific Standard Time (PST) on 26 December 2003, during the waning phase of a severe winter storm. Approximately $200 \mathrm{~m}^{3}$ (540 metric tons) of rock detached from an area of $\sim 110 \mathrm{~m}^{2}$ on the northeast side of the bedrock fin (Figs. 3, 4); according to the criteria of Wieczorek and Snyder (2004), this was a medium sized rock fall. The rock mass free fell $\sim 20 \mathrm{~m}$ onto bedrock joint surfaces, and continued northeast $\sim 370 \mathrm{~m}$ horizontally and $480 \mathrm{~m}$ vertically to the base of Staircase Falls. Numerous boulders as large as $11 \mathrm{~m}^{3}$ in volume fell to the talus at the base of Staircase Falls, with some boulders coming to rest near the lower limit of the talus slope (Fig. 5). The impact of the rock debris onto the talus at the base of Staircase Falls generated airborne rock fragments that extended well into a developed portion of Curry Village (Fig. 1). These airborne fragments, termed flyrock by Wieczorek and Snyder (1999), often have trajectories much different than the original falling rock mass, and can travel far beyond the base of talus slopes. Several distinct flyrock fragments and impact marks extended as much as $75 \mathrm{~m}$ beyond the base of the talus (Fig. 1). Fourteen cabins in Curry Village were struck by flyrock, and two other cab-

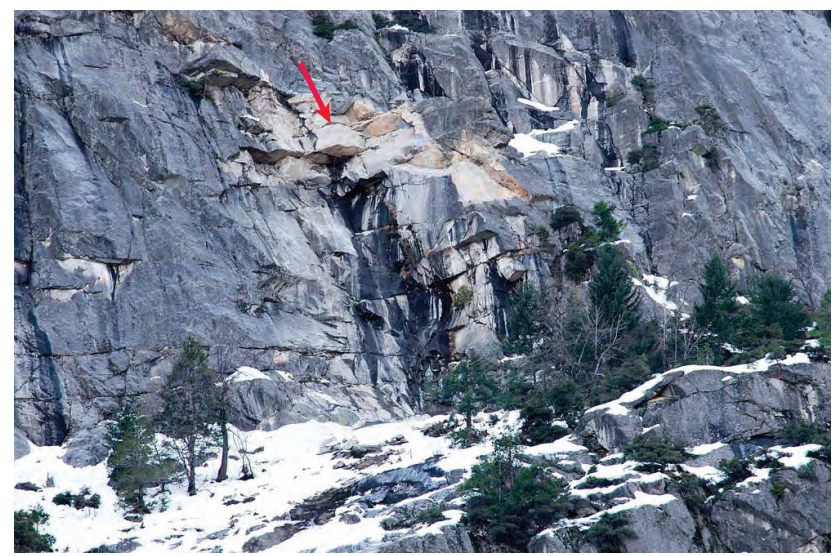

Fig. 4. Photograph of Staircase Falls rock-fall detachment area taken 21 days after 26 December 2003 event, showing light colored joint-controlled detachment surfaces. Rock debris impacted snowcovered ledge immediately below source area, and then fell $\sim 745 \mathrm{~m}$ down joint-controlled ledges to Yosemite Valley floor. Note heavy dark drainage paths below detachment area indicating water flow through joints. Overhanging rectangular block in center left of photograph (marked by red arrow) fell during 9 June 2007 rock fall. (Photo by Dan Horner, NPS).

ins were splattered with mud when flyrock fragments landed nearby. Park visitors occupied these cabins at the time of the rock fall, but there were only minor injuries (Wieczorek and Snyder, 2004).

Subsequent observation of the detachment area in April 2004 revealed additional potentially unstable rock in the form of a fractured, jointed, and moderately weathered bedrock fin (Fig. 3). We estimated the volume of potentially unstable rock remaining at the detachment area, in the form of the narrow bedrock fin (Fig. 3), to be $\sim 350 \mathrm{~m}^{3}$. Only a few meters of rock separate the Staircase Creek channel in LeConte Gully from the active detachment surface of the Staircase Falls source area (Fig. 3).

Some of the rock debris generated by the 26 December 2003 rock fall did not reach the base of the cliff, but instead remained perched on the joint-controlled ledge immediately below the detachment area. In fact, rock debris from the 26 December 2003 event added to debris that had previously accumulated on the ledge, presumably from prehistoric rock falls originating from the Staircase Falls detachment area. We estimated the cumulative volume of rock debris after the 26 December 2003 event to be $\sim 840 \mathrm{~m}^{3}$. The debris rests on bedrock ledges dipping between 35 and $40^{\circ}$ to the northeast, toward the west end of Curry Village, presenting an additional hazard associated with the Staircase Falls rock-fall detachment area. 


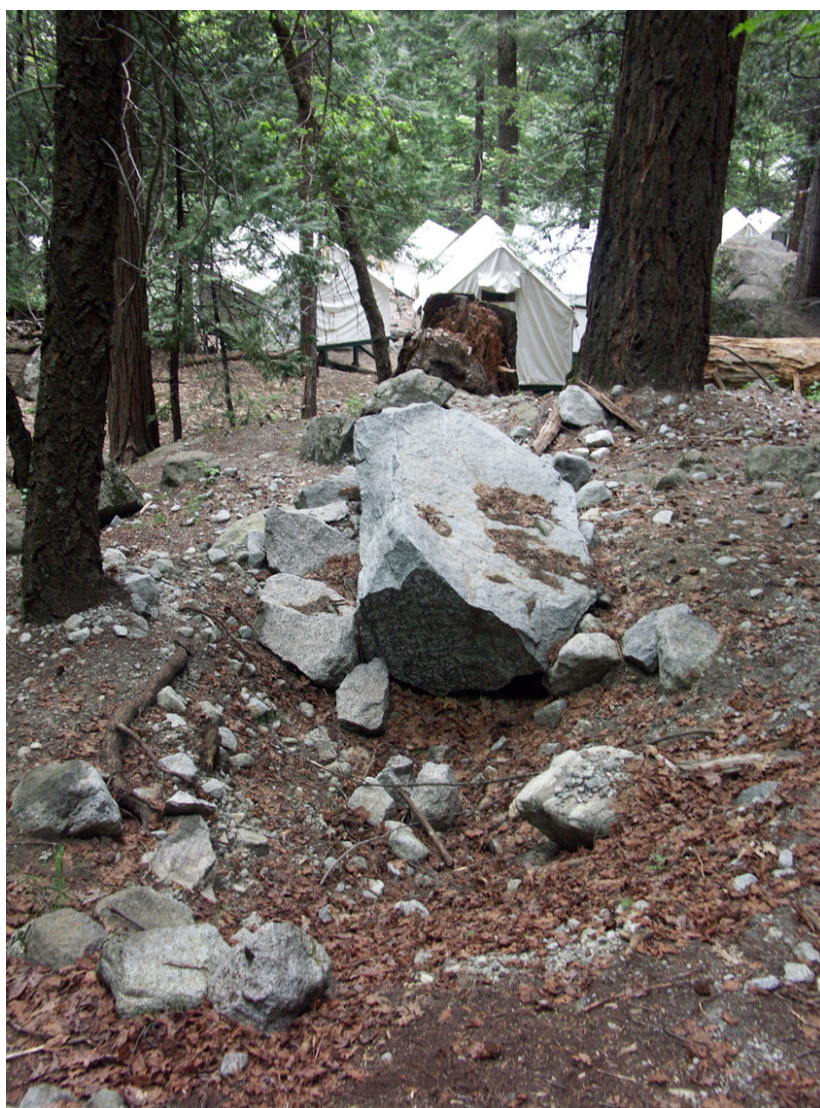

Fig. 5. Part of rock-fall deposit from 26 December 2003 Staircase Falls rock fall. $4 \mathrm{~m}^{3}$ (11 metric tons) block landed $\sim 120 \mathrm{~m}$ beyond base of cliff, leaving prominent impact crater.

\subsection{June 2007 rock fall}

At 02:53 PST on 9 June 2007, another rock fall occurred from the Staircase Falls detachment area. The 9 June 2007 rock fall consisted of an $18 \mathrm{~m}^{3}$ (49 metric tons) block that fell from the middle portion of the 26 December 2003 rock fall detachment area (Figs. 3, 6). This was a small sized rock fall according to the criteria of Wieczorek and Snyder (2004). This block fell to the large ledge immediately below the detachment area, sweeping additional debris off the edge. Debris fell onto a large area of the talus slope near the base of Staircase Falls, sending flyrock into the first row of visitor cabins along the southwestern edge of Curry Village. Flyrock fragments struck one cabin, but there were no injuries. Assessment of the detachment area later that day revealed that the rock fall consisted of a prominent rectangular overhanging block (Fig. 6), identified previously as a potential hazard. Prior to failure, this block was bounded on all sides by open fractures, with tree roots projecting from fractures at the base of the block (Fig. 6).

\subsection{July 2007 rock fall}

At 10:25 PST on 26 July 2007, yet another small rock fall initiated from the Staircase Falls detachment area. A block $\sim 8 \mathrm{~m}^{3}$ in volume (21 metric tons) detached from the source area and landed on the large ledge immediately below. This was a small sized rock fall according to the criteria of Wieczorek and Snyder (2004). Most of the rock debris apparently stayed on the ledge below the detachment area, adding to the total volume of debris there, but a few small $\left(<1 \mathrm{~m}^{3}\right)$ boulders did impact the talus slope at the base of the cliff. No debris extended beyond the base of the talus.

\subsection{Rock-fall triggering mechanisms}

The 26 December 2003 Staircase Falls rock fall was closely associated in time with a severe winter storm that dropped $102 \mathrm{~mm}$ of precipitation in Yosemite Valley between 24 26 December (Fig. 7). This storm triggered at least two other rock falls or rock slides in Yosemite Valley (Wieczorek and Snyder, 2004), and also a debris flow from LeConte Gully (Figs. 1, 2). The debris flow emanating from LeConte Gully, immediately adjacent to the Staircase Falls source area, suggests that stream discharge in Staircase Creek was substantially elevated at the time of the Staircase Falls rock fall. Precipitation during the storm fell initially as rain and later as snow, as air temperatures dropped $5.5^{\circ} \mathrm{C}$ from the onset of precipitation to the time of failure; prior to failure, the detachment area experienced $24 \mathrm{~h}$ of subfreezing air temperatures (Fig. 7). Lacking monitoring data from the detachment surface at the time of the rock fall, we are unable to attribute with certainty a specific triggering mechanism to the 26 December 2003 event. However, we suggest that meteorological conditions likely triggered the 26 December 2003 rock fall by one or a combination of several mechanisms. First, increased precipitation and Staircase Creek discharge may have increased infiltration into joints at the source area, increasing cleft (water) pressures and triggering the rock fall. Second, subfreezing air temperatures may have propagated to the detachment surface, causing freezing of water in joints and triggering the rock fall by frost wedging. Finally, the rock fall may have been triggered by a combination of increased groundwater flow and subfreezing temperatures, with ice lenses in near-surface joints constricting groundwater flow and elevating cleft pressures. Regardless of the exact triggering mechanism, temporal correspondence of the rock fall with the 24-26 December storm suggests that meteorological conditions triggered the rock fall.

Unlike the 26 December 2003 event, the 9 June and 26 July 2007 events were not clearly associated with a triggering event. Both rock falls occurred during periods of warm, dry summer weather following an exceptionally dry winter in Yosemite National Park. Air temperature at the detachment area was $\sim 8^{\circ} \mathrm{C}$ at the time of the 9 June rock fall (with a minimum temperature of $4^{\circ} \mathrm{C}$ and a maximum temperature 

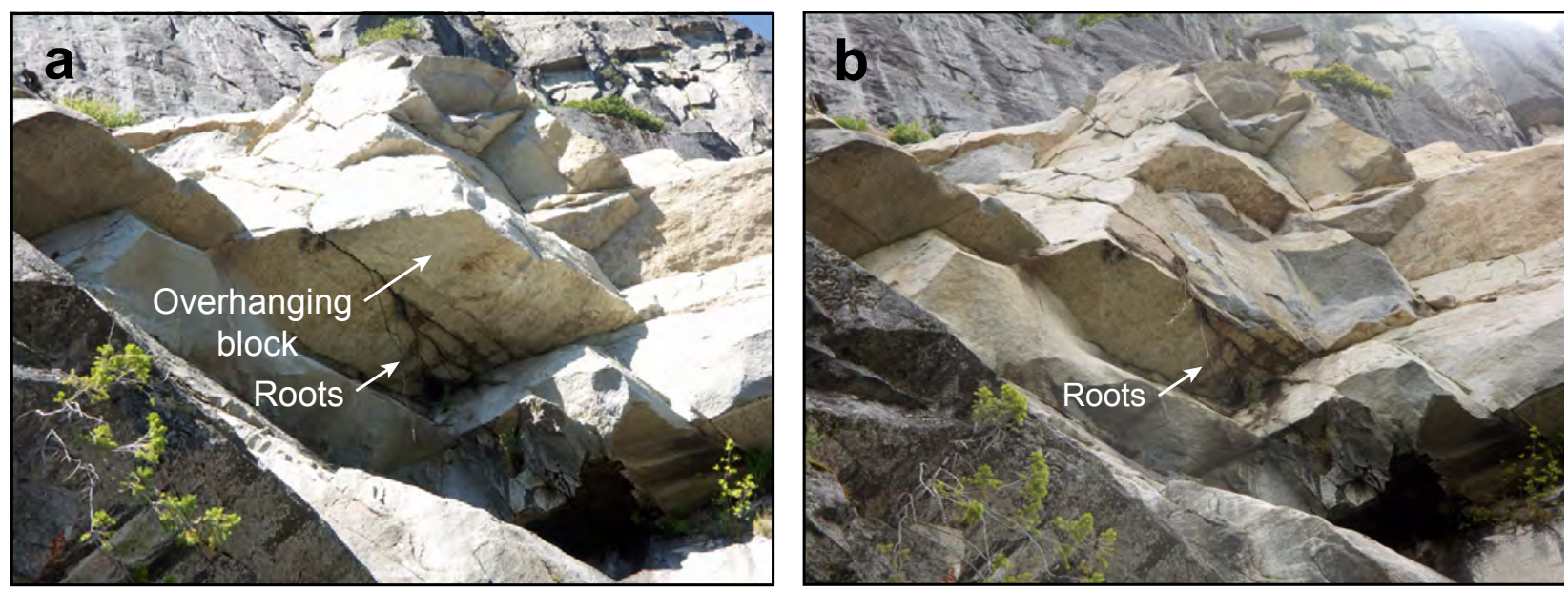

Fig. 6. Staircase Falls rock-fall detachment area (a) before and (b) after 9 June 2007 rock fall, which consisted of failure of overhanging rectangular block, bounded by open fractures containing roots, in center of photo (a). Dark stain in lower right of both photographs results from seepage of Staircase Creek through bedrock fin.

of $22^{\circ} \mathrm{C}$ over the preceding $24 \mathrm{~h}$ ), and $\sim 26^{\circ} \mathrm{C}$ at the time of the 26 July rock fall (with a minimum temperature of $15^{\circ} \mathrm{C}$ and a maximum temperature of $31^{\circ} \mathrm{C}$ over the preceding $24 \mathrm{~h}$ ); in both cases, temperatures were well above the range of freeze-thaw activity. Close observation of the detachment area approximately $10 \mathrm{~h}$ after the 9 June 2007 rock fall showed that, although water from Staircase Creek was seeping from joints several meters below the detachment area, the specific detachment surface of the overhanging rectangular block was completely dry (Fig. 6). The detachment area was also dry during the 26 July 2007 event. Thus, a specific hydrologic triggering mechanism for either the 9 June or 26 July 2007 rock falls is unlikely. No seismic activity was detected at the time of these failures. Relict roots associated with a pine tree that fell during the 26 December 2003 rock fall (and thus were not growing at the time of the 9 June 2007 rockfall) were observed projecting from a fracture at the base of the overhanging rectangular block that failed on 9 June 2007 (Fig. 6). Although root wedging probably did not trigger the rock fall, it likely contributed to failure by progressively wedging open the block-bounding fractures. In the absence of compelling triggering mechanisms such as seismic activity, precipitation, snowmelt, groundwater flow, and/or freeze-thaw conditions, we report both the 9 June and 26 July 2007 Staircase Falls rock falls as having unrecognized triggering mechanisms. These rock falls illustrate the difficulty of reliably attributing triggering mechanisms to rock falls in Yosemite Valley without detailed monitoring of the detachment area at the time of failure.

\section{Rock fall causative factors}

Given that recent failures from the Staircase Falls detachment area occurred over a range of meteorological conditions, and

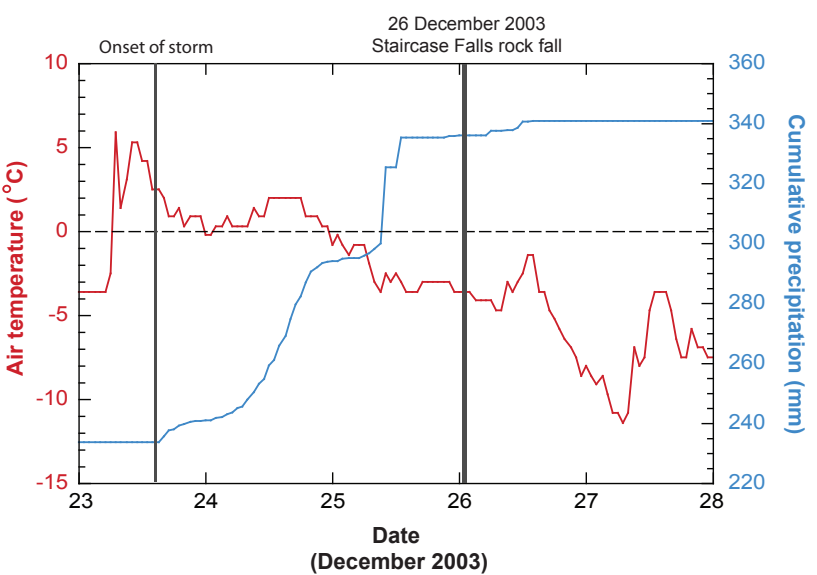

Fig. 7. Air temperature (red line) and cumulative annual precipitation (blue line) for 23-28 December 2003. Dashed horizontal line marks $0^{\circ} \mathrm{C}$. Thin black bar marks onset of storm. Thick black bar marks 26 December 2003 Staircase Falls rock fall, which occurred after $102 \mathrm{~mm}$ of precipitation fell over previous $48 \mathrm{~h}$, and after $24 \mathrm{~h}$ of sub-freezing temperatures. Data from Yosemite Valley weather station (Station YYV, California Department of Water Resources, California Data Exchange Center, http://cdec.water.ca.gov/), with air temperatures scaled to detachment area elevation assuming an adiabatic lapse rate of $-0.65^{\circ} \mathrm{C} / 100 \mathrm{~m}$ (Lunquist and Cayan, 2007).

in two cases without recognizable triggers, we evaluated the geologic and hydrologic factors that contributed to failure. These causative factors include bedrock lithology and weathering, joint spacing and orientation controlling detachment and subsequent debris travel paths, and hydrologic processes affecting slope stability. 
Table 1. Joint systems in the Glacier Point region.

\begin{tabular}{lllllll}
\hline ID\# & ID direction & \# Joints & Trend $\left(^{\circ}\right)$ & Plunge $\left(^{\circ}\right)$ & Strike $\left(^{\circ}\right)$ & Dip $\left(^{\circ}\right)$ \\
\hline J1 & Parallel to topographic surface & - & - & - & - & - \\
J2 & NE & 20 & 78.8 & 28.8 & 168.8 & $28.8 \mathrm{E}$ \\
J3 & NE vertical & 18 & 69.4 & 86.5 & 159.4 & $86.5 \mathrm{E}$ \\
J4 & NE flat & 7 & 79.0 & 14.4 & 169.0 & $14.4 \mathrm{E}$ \\
J5 & W flat & 4 & 263.4 & 20.0 & 173.4 & $20.0 \mathrm{~W}$ \\
J6 & SW & 35 & 240.9 & 51.5 & 150.9 & $51.5 \mathrm{SW}$ \\
J7 & W vertical & 13 & 256.6 & 82.3 & 166.9 & $82.3 \mathrm{~W}$ \\
J8 & SE & 19 & 127.1 & 42.1 & 37.1 & $42.1 \mathrm{SE}$ \\
J9 & NW & 17 & 324.6 & 53.5 & 54.6 & $53.5 \mathrm{NW}$ \\
J10 & N vertical & 17 & 355.4 & 82.8 & 85.4 & $82.8 \mathrm{~N}$ \\
J11 & SE vertical & 19 & 163.1 & 85.3 & 73.1 & $85.3 \mathrm{~S}$ \\
J12 & NW steep & 9 & 321.7 & 78.6 & 51.6 & $78.6 \mathrm{NW}$ \\
J13 & S flat & 8 & 191.2 & 21.6 & 101.2 & $21.6 \mathrm{~S}$ \\
\hline
\end{tabular}

a More joints exist than were measured.

${ }^{b}$ Sheeting joints are not reported because they form parallel to topographic surfaces at all orientations.

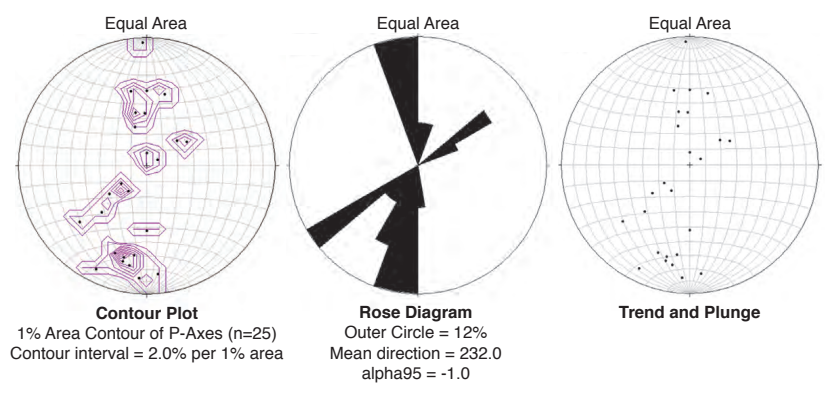

Fig. 8. Contour plots, rose diagrams, and trend and plunge data for joint surfaces at Staircase Falls rock fall detachment area $(n=25)$ (see Table 1 for data). More joints exist than were measured.

\subsection{Lithology}

The bedrock geology of Yosemite Valley is comprised of several different types and ages of intrusive igneous rocks, primarily Cretaceous granite, granodiorite, tonalite, and quartz diorite (Calkins et al., 1985; Peck, 2002). The rocks in the vicinity of Glacier Point and Staircase Falls are predominantly Late Cretaceous Sentinel, Glacier Point, and Half Dome granodiorites (Calkins et al., 1985; Peck, 2002). Although the contact between the Glacier Point and Half Dome granodiorites is near the Staircase Falls detachment area, there is no clear correlation in the Glacier Point area between rock type and either joint density, weathering patterns, or rock fall frequency.

\subsection{Glaciation and weathering}

The eastern portion of Yosemite Valley was deepened and widened during several episodes of glacial erosion (Matthes,
1930; Huber, 1987). The latest (Tioga) glacial advance peaked about 20000 yr BP (Bursik and Gillespie, 1993) and had retreated from Yosemite Valley by about $17000 \mathrm{yr}$ BP. Unlike earlier glaciers, the Tioga glacier did not overtop Yosemite Valley, but rather reached only part way up the valley walls (Matthes, 1930). Thus, the cliffs below the Tioga trimline were recently scoured by glacial erosion, whereas those areas above the Tioga trimline have been weathering for much longer, perhaps $>780000$ years ago (Matthes, 1930; Sharp, 1968; Smith et al., 1983). The upper cliffs are moderately-to-deeply weathered, increasing water infiltration and ice wedging in near surface joints; weathering is accelerated and weathered rock zones are thickest where granitic rocks are most frequently wet (e.g., Wahrhaftig, 1965; Twidale and Vidale Romani, 2005). For this reason, and perhaps because of greater tensile stresses in the upper portions of Yosemite Valley cliffs, large rock falls are more common there.

The Staircase Falls detachment area is above the inferred Tioga trimline (Matthes, 1930), and thus has been exposed to prolonged weathering. The greater surface area of the bedrock fin may also have enhanced weathering of the detachment area.

\subsection{Jointing}

We have identified as many as 13 joint sets (J1-J13) in the Glacier Point region (Table 1) and labeled them following the methodology of Wieczorek and Snyder (1999). The most prominent joints in the Glacier Point region are the near vertically oriented regional-scale joints $(\mathrm{J} 3, \mathrm{~J} 7, \mathrm{~J} 10$ and $\mathrm{J} 11)$, which are clearly visible in LandSAT imagery (e.g., US Geological Survey, 1986). The overall structure of the cliff surfaces at Glacier Point and prominent local landforms such as 
LeConte Gully (Fig. 2) are controlled by these regional-scale joints, which intersect nearly all others. Joint $\mathbf{J} 2$ is a pervasive ledge-forming discontinuity below Glacier Point with steep dips of approximately $30^{\circ}$ to the east (Fig. 2). This orientation is similar to the set of discontinuities that form the stair "treads" of Staircase Falls and the broad ledge carrying the abandoned "Ledge Trail" (Fig. 2). Also prominent are sheeting (J1) joints, also known as exfoliation joints, which form parallel to topographic surfaces (e.g., Matthes, 1930; Bahat et al., 1999; Martel, 2006). J1 joints have strongly influenced cliff retreat back from the original joint-controlled surfaces, exposing with time the inclined steps of Staircase Falls (Huber, 1987). Overburden depth can affect spacing and openness of joints, particularly $\mathrm{J} 1$ sheeting joints; the cliff faces below Glacier Point, particularly areas with topographic complexity (e.g., bedrock features that project out from the mean cliff surface), possess joints that are wider and more hydrologically conductive than those joints deeper below the ground surface.

The intersection of joints along a slope can be analyzed to determine whether rock falls, slides or topples are likely (e.g., Norrish and Wyllie, 1996). In Yosemite Valley, sheeting joints parallel to a cliff surface are often responsible for rock falls. For example, the source area for the $\sim 560 \mathrm{~m}^{3}$ rock fall that occurred on 16 November 1998 above the eastern part of Curry Village contained intersecting joints J2 through J6 (Wieczorek and Snyder, 1999). However, none of the joint planes or joint plane intersections at the Curry Village detachment area formed plane or wedge conditions favorable for sliding or toppling, primarily because the direction and inclination of the cliff face were not optimally oriented for these failure types. Joint planes and joint-plane intersections at the Curry Village detachment area define the top and lateral boundaries of an exfoliation sheet segment along which failure occurred. Although joint sets J2 through J6 did not form the detachment surface, they did determine the size of exfoliation sheet segments that failed during the 1998 rock fall (Wieczorek and Snyder, 1999).

Measurements of 25 joints at and near the Staircase Falls detachment area (Fig. 8) reveal at least 19 joints of three major joint sets (J6, J9, J13). Assuming a static friction strength of $\geq 35^{\circ}$ for granitic rock (Barton and Choubey, 1977), we evaluated the initial slope of the detachment area, which dips approximately $60^{\circ}$ northeast, with each of the three major joint planes and possible joint plane intersections. The results suggest that the 26 December 2003 failure occurred primarily along a $\mathrm{J} 9$ joint surface, with an average dip of $53^{\circ}$ north. The subsequent travel paths of rock debris were strongly influenced by the east-trending $\mathrm{J} 2$ joint sets that form the Ledge Trail ledge and the treads of Staircase Falls (Figs. 1, 2).

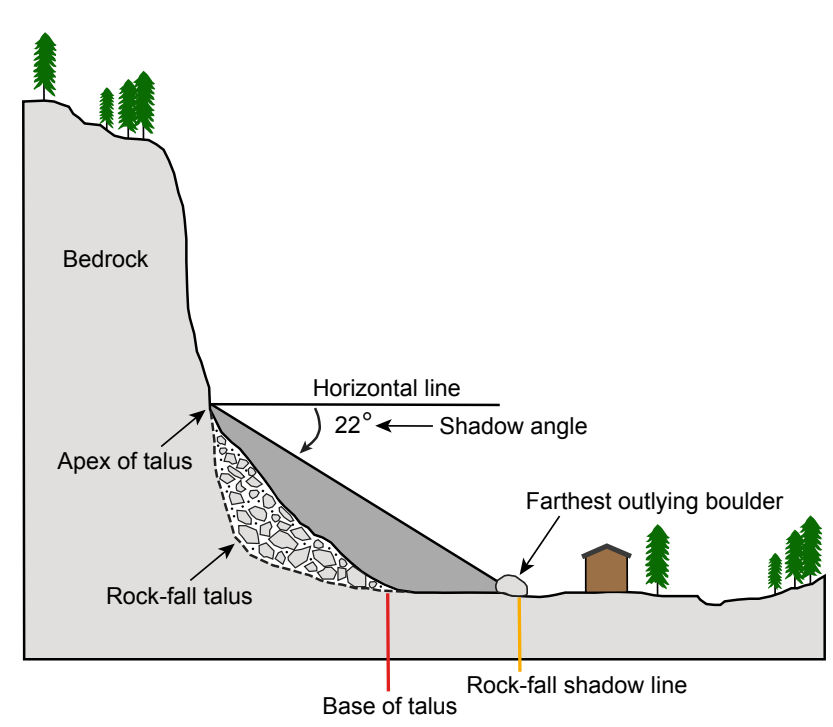

Fig. 9. Schematic of rock-fall talus slope, base of talus (red line), and farthest outlying boulder, illustrating determination of rock fall shadow angle and shadow line (orange line); after Wieczorek et al. (1998, 1999), modified from Evans and Hungr (1993).

\subsection{Hydrology}

Quantitative hydrologic characterization of groundwater flow at Glacier Point is severely limited by access to the subsurface. We gained semi-quantitative understanding of subsurface hydrology at Glacier Point by examining precipitation, stream flow, spring flow, cliff seepage, and water use data at Glacier Point visitor facilities. We interpreted this information in the context of previous detailed subsurface hydrologic investigations elsewhere in Yosemite National Park (Borchers, 1996).

Regional joints in the Yosemite region provide first order structural control on drainage orientation (e.g., Ericson et al., 2005). In the Glacier Point region, the most prominent hydrological influence is from the near vertical regionalscale joints (J3, J7, J10 and J11). J12 joints are the primary structural control on upper Staircase Creek where it flows from Glacier Point down through the upper portion of LeConte Gully. Because most precipitation at Glacier Point falls as snow, surface streams such as Staircase Creek and subsurface joints in the Glacier Point region are primarily recharged from snowmelt in the late spring and summer. Staircase Creek gains flow from groundwater discharging to the stream channel upstream of the top of Staircase Falls (J. Borchers, unpublished data). However, just upstream of the point where Staircase Creek leaves LeConte Gully and turns northeast to the top of Staircase Falls, some water infiltrates into joints in the stream channel and moves northeast through fractures in the narrow bedrock fin separating LeConte Gully from Staircase Falls. Moderately weathered J9 joints in this bedrock fin are likely conduits for water seeping through to the Staircase Falls source area. Photographs 

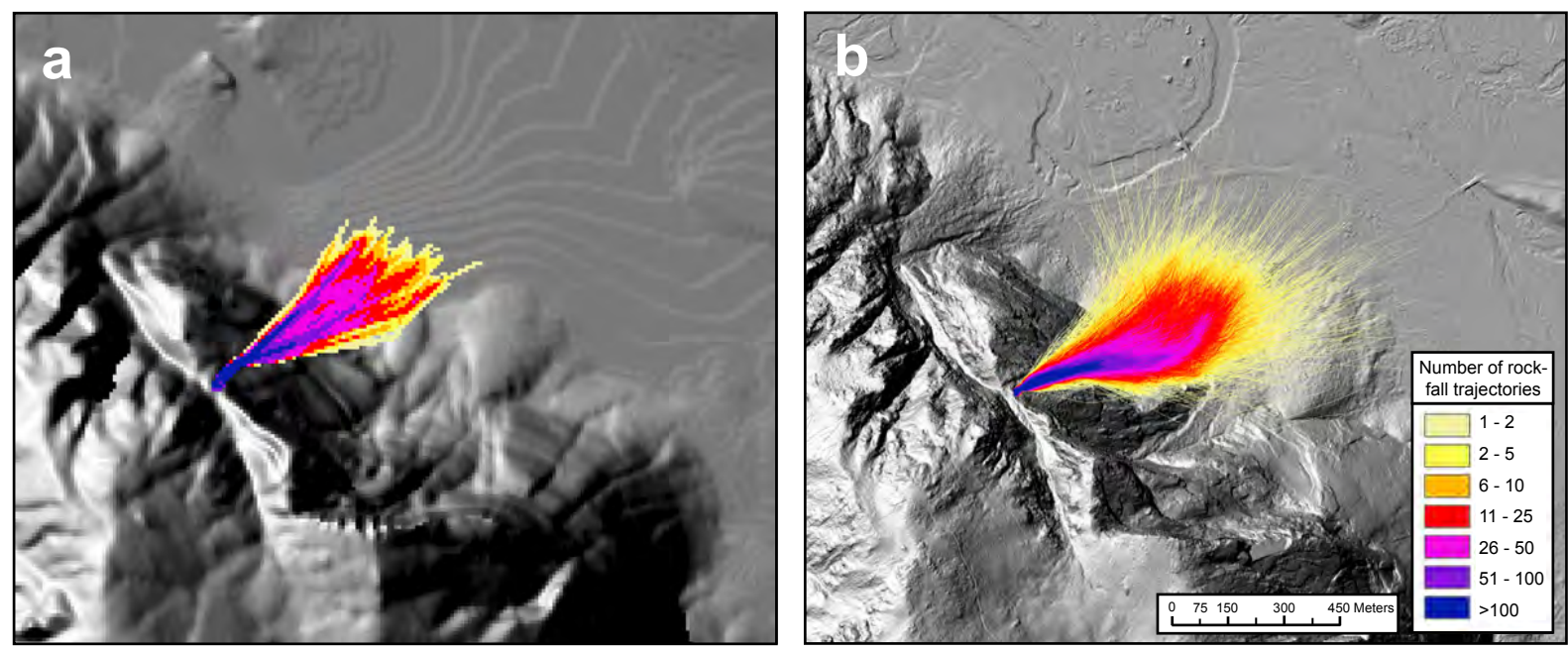

Fig. 10. Comparison of STONE rock-fall simulations on Digital Elevation Models (DEMs) of varying resolution. Colors show number of rock-fall trajectories. (a) simulation performed on $10 \mathrm{~m}$ DEM showing 100 blocks launched from each DEM cell of detachment area (6 cells) for total of 600 rock fall trajectories. (b) Simulation performed on filtered (bare earth) $1 \mathrm{~m}$ DEM derived from airborne LiDAR data, showing 100 blocks launched from each DEM cell of detachment area (112 cells) for total of 11200 rock fall trajectories.

of the Staircase Falls source area taken 21 days after the 26 December 2003 rock fall showed water streaming from joints below the source area (Fig. 4). Water discharging from the source area is adequate to support perennial hydrophytic vegetation. Each failure from the Staircase Falls detachment area decreases the width of the bedrock fin between LeConte Gully and Staircase Creek, potentially increasing infiltration from Staircase Creek through the fin, and also permitting winter ice to form deeper in the cliff face. Each failure thus accelerates joint weathering in this fin, increasing the probability of future rock falls from this location.

\section{Hazard assessment}

5.1 Rock fall potential from talus deposits and historical events

In the mid-1990s, the USGS developed a map of rock fall potential in Yosemite Valley to support park planning efforts (Wieczorek et al., 1998, 1999). This information is used to guide placement of future development in Yosemite Valley, with the stipulation that future facilities generally not be planned within the talus area. Rock fall potential was mapped on the basis of historically recorded rockfall deposits, surface evidence of talus, and scattered outlying boulders beyond the base of talus slopes. Rock fall impact areas, including flyrock, were mapped not only for safety around facilities, but also to determine how actual rock falls of different sizes and behaviors correlated with the rock-fall potential map. The map has a line delineating the base of the talus slopes (Fig. 9), which also includes the extent of debris flows onto the floor of Yosemite Valley.
To compensate for a lack of subsurface data on the full extent of rock falls, Wieczorek et al. $(1998,1999)$ assessed rock-fall hazard beyond the base of talus slopes, where infrequent rock-fall events may stop, using the rock-fall shadow concept (Evans and Hungr, 1993). The rock-fall shadow zone is determined using the angle from horizontal extending from the apex of the talus slope to the farthest outlying boulder (Fig. 9; Evans and Hungr, 1993). Based on analyses of 25 outlier boulders, a minimum shadow angle of $22^{\circ}$ was selected to define the rock-fall shadow line in Yosemite Valley (Fig. 9; Wieczorek et al., 1998, 1999). Determination of the rock-fall shadow line did not take into account large rock avalanche runout distances, potential airblast areas, or flyrock ranges. According to the resulting rock-fall potential map, some existing facilities below Staircase Falls are situated on the toe of talus slopes, and most are within the rock-fall shadow zone (Wieczorek et al., 1998, 1999).

\subsection{Hazard assessment using STONE rock fall simulations}

Although the rock-fall shadow line provides useful firstorder hazard assessment, in some instances rock-fall hazards are not well represented by the shadow line concept because the use of the talus apex is somewhat arbitrary, because it does not represent well those areas that have not produced large talus deposits, and because complex topography above the talus can influence the distribution of rockfall debris (e.g., Guzzetti et al., 2003). To more accurately assess the extent of areas below Staircase Falls potentially subject to future rock falls, we employed STONE, a physically based computer program that simulates rock fall events in three dimensions (Guzzetti et al., 2002, 2003; Agliardi and Crosta, 2003). STONE provides relevant information 

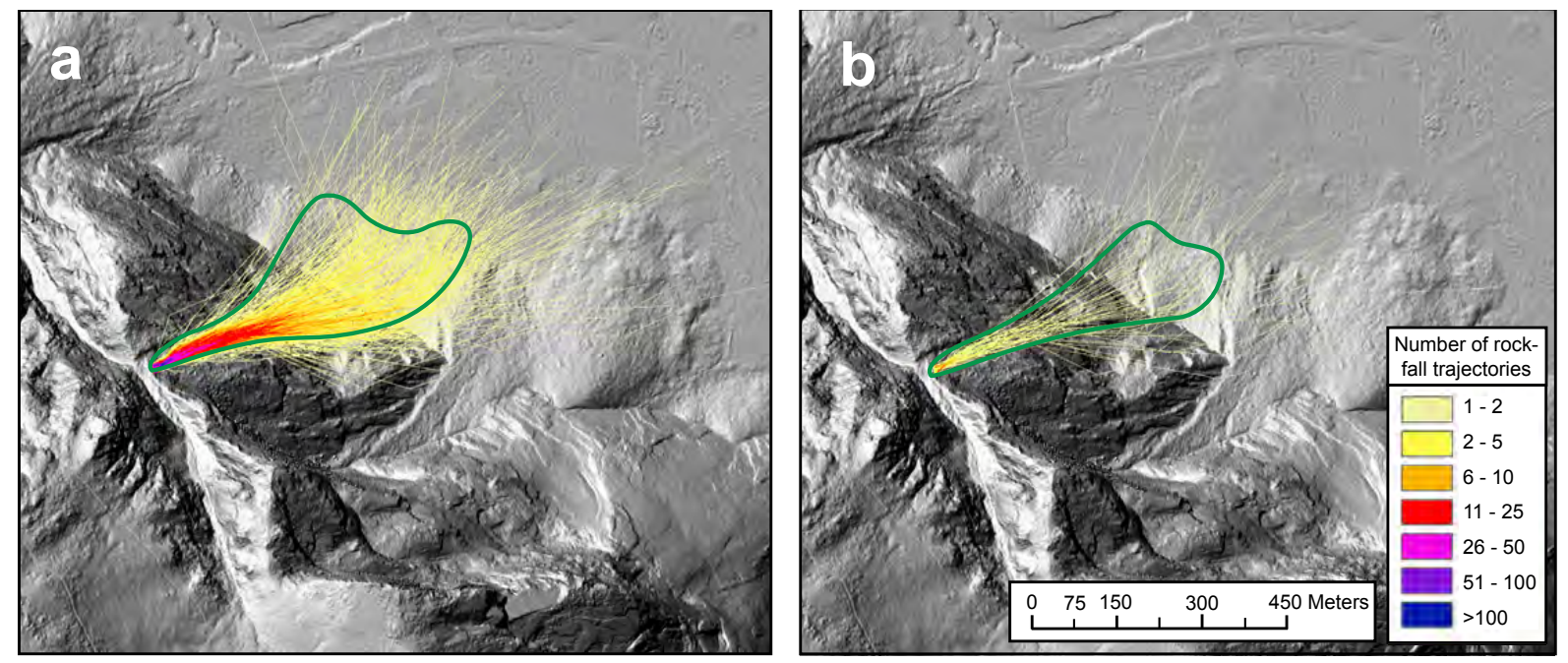

Fig. 11. Comparison of STONE model simulations and mapped extent of rock debris for 2003 and 2007 Staircase Falls rock falls. Colors show number of rock-fall trajectories. (a) Simulation of 26 December 2003 rock fall, with 10 blocks launched from each DEM cell of detachment area (112 cells) for total of 1120 rock fall trajectories. Mapped limit of actual rock debris (excluding flyrock) shown by green line. (b) Simulation of 9 June 2007 rock fall, with 1 block launched from each DEM cell of detachment area (112 cells) for total of 112 rock fall trajectories. Mapped limit of actual rock debris (excluding flyrock) shown by green line.

to assess rock-fall hazard and risk, and has previously been used to assess hazard and risk in Yosemite Valley (Guzzetti et al., 2003). The input data required by STONE include: (1) a digital elevation model (DEM) of the rock-fall detachment area and potential runout area; (2) the location and size of the detachment area; (3) the initial velocity and the starting angle (degrees from horizontal) for each rock fall; (4) a velocity threshold below which the block stops; and (5) the coefficients of dynamic rolling friction, normal energy restitution, and tangential energy restitution used to simulate the loss of energy when rolling and at impact points (Chau et al., 2002). STONE uses a lumped mass approach to simulate rock falls, i.e., each rock fall block is considered dimensionless with all of the mass concentrated in a point (the center of mass). The model accounts for the inherent natural variability in the input data by "launching" a variable number of blocks from each cell of the detachment area, and by varying randomly the starting angle, the dynamic rolling friction coefficient, and the normal and tangential energy restitution coefficients. For each DEM cell, STONE produces results in raster maps portraying: (1) the cumulative count of rock fall trajectories that passed through each cell; (2) the maximum computed velocity; and (3) the maximum height of a block from the ground computed along the rock fall trajectories (i.e., the block bounce height).

We performed three sets of simulations with the STONE model:

1. A comparison of results from $10 \mathrm{~m}$ and $1 \mathrm{~m}$ DEMs,

2. a comparison of simulated Staircase Falls rock falls with the actual distribution of rock debris from these events, and
3. a suite of simulations designed to assess the rock fall runout areas from potential future Staircase Falls rock falls.

We used input values, initial model conditions, and model parameters previously calibrated for Yosemite Valley (Guzzetti et al., 2003).

First, to assess the affect of varying DEM resolution on model output we simulated an unspecified rock-fall from the Staircase Falls detachment area performed on a $10 \mathrm{~m}$ resolution DEM, and compared this with a simulation of the same rock fall performed on a higher resolution $1 \mathrm{~m}$ DEM (Fig. 10). The $1 \mathrm{~m}$ DEM was produced from filtered (i.e., bare earth) airborne Light Detection and Ranging (LiDAR) data, and reveals subtle topographic features not resolved in the $10 \mathrm{~m}$ DEM. As such, the increased resolution of the 1 $m$ DEM significantly improved the resolution of the STONE model results (Fig. 10). It is difficult to directly compare results from the $1 \mathrm{~m}$ and $10 \mathrm{~m}$ DEMs because they necessarily have a different number of source cells and, hence, produce a different number of rock-fall trajectories. Nevertheless, there are some visible differences between the two simulations. For example, the path of highest cumulative count of rock-fall trajectories shifted to the east in the $1 \mathrm{~m}$ DEM simulation, presumably due to subtle topographic features below the detachment area that are not resolved in the $10 \mathrm{~m} \mathrm{DEM}$ (Fig. 10). The greater resolution of the $1 \mathrm{~m}$ DEM increases the dispersion of rock fall trajectories, a result consistent with those described in previous rock fall model comparisons (Lan and Martin, 2007; Agliardi and Crosta, 2003). Rockfall trajectories generally extended farther from the base of cliffs in the $1 \mathrm{~m}$ DEM than in the $10 \mathrm{~m}$ DEM (Fig. 10), a 

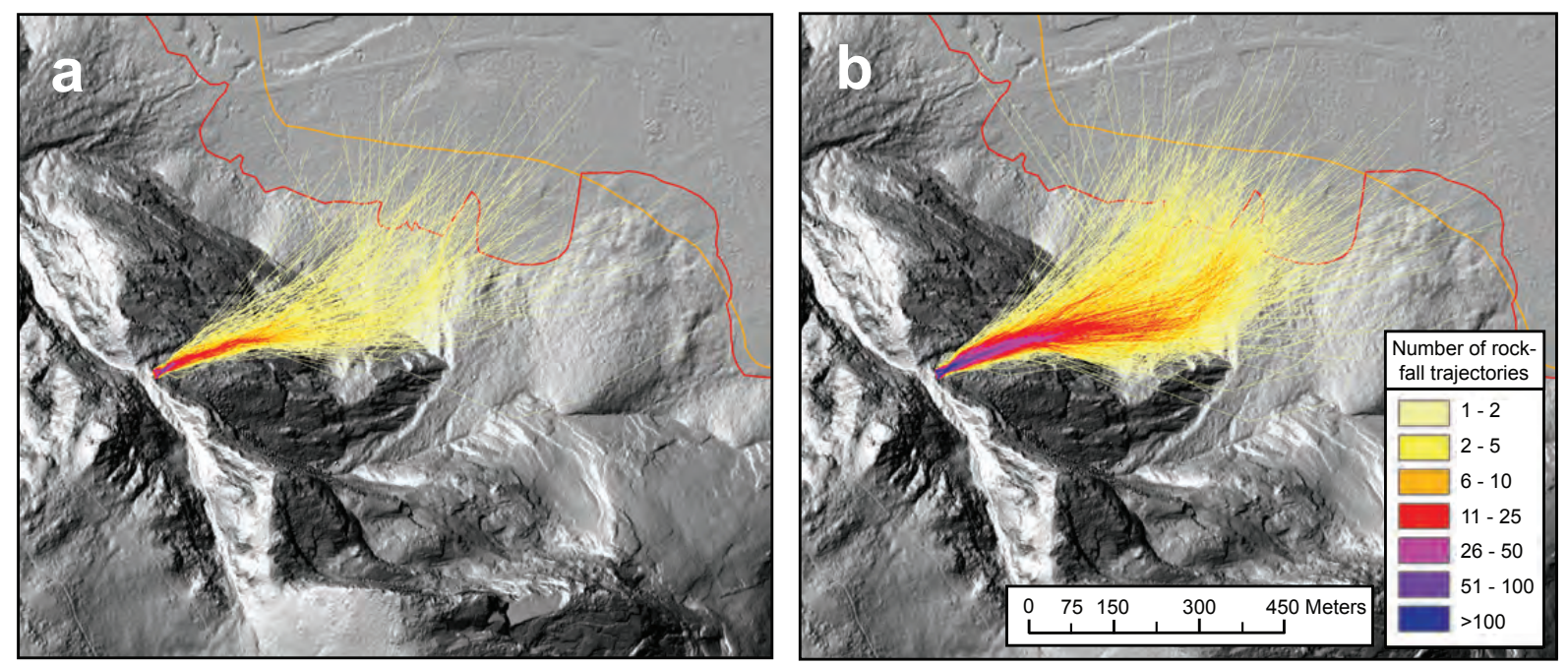

Fig. 12. Assessment of future rock-fall hazard from Staircase Falls detachment area with example STONE simulations of (a) 6 blocks (672 trajectories) and (b) 20 blocks (2240 trajectories) launched from each DEM cell of detachment area (112 cells), representing partial and total failure of remaining rock mass, respectively. Colors show number of rock-fall trajectories. Red line delineates base of talus (including debris flow deposits), orange line is rock-fall shadow line (Wieczorek et al., 1998, 1999).

robust result independent of the number of detachment area DEM cells or the number of blocks launched. Overall, the increased spatial resolution of the $1 \mathrm{~m}$ DEM allows for more effective three-dimensional rock fall simulations (Agliardi and Crosta, 2003).

Using the $1 \mathrm{~m}$ DEM, we then simulated the 26 December 2003 and 9 June 2007 rock falls and compared the results with the actual distribution of rock debris mapped in the field (Fig. 11a, b). Overall, the simulated rock-fall trajectories match well the actual mapped distribution of rock debris, with the majority of simulated trajectories falling within the zone of actual rock debris deposition. Furthermore, many observed dynamics of the Staircase Falls rock falls are displayed in the simulations, including the strong influence on trajectories of the east-trending $\mathrm{J} 2$ joint surfaces below the detachment area and the morphology of the talus slope (Fig. 11a, b). For both the 2003 and 2007 event simulations, a small number of trajectories extended farther from the base of the cliff than the mapped distribution of rock debris (Fig. 11a, b). This apparent "overshoot" of the simulated trajectories may be due to several factors. First, some values we assume for input data may not accurately represent the range of rock-dynamics (e.g., Lan and Martin, 2007); although we have assumed reasonable values for these input parameters (Lan and Martin, 2007; Chau et al., 2002), specifically calibrated to Yosemite Valley rock falls (Guzzetti et al., 2003), we cannot empirically verify them, resulting in some uncertainty. Second, STONE does not account for certain factors such as block shape, air drag, block fracturing, and/or energy dissipation by vegetation in the impact zone. Although the filtered (bare earth) $1 \mathrm{~m}$ DEM is a substantial improvement over the previously available $10 \mathrm{~m}$ DEM, even it does not capture certain roughness elements in the landscape, such as talus interstices, that can diminish the distance rock debris travels beyond the base of the cliff. Finally, the mapped distribution of rock-fall debris may be somewhat in error, because small rock fragments can be difficult to locate, and also to confirm as fresh rock fall debris. In the case of the 26 December 2003 rock fall, mapping of rock debris was further complicated by $30 \mathrm{~cm}$ of snow that accumulated during and immediately after the event. Regardless of the cause(s) of overshoot of some rock-fall trajectories, only those trajectories resulting from the most unfavorable combination of modeling parameters and local topography reach these maximum runout positions; thus, these trajectories represent very low probability events. As noted by Agliardi and Crosta (2003), the conservative approach from a hazard assessment perspective is to calibrate rock-fall simulations such that the maximum extent of mapped rock debris is simulated by the average computed runout.

Finally, considering that $\sim 320 \mathrm{~m}^{3}$ of potentially unstable rock remains at the detachment area, we used STONE to assess rock-fall hazards associated with potential future Staircase Falls rock falls (Fig. 12a,b). Because STONE treats each block as a dimensionless point-mass, we cannot explicitly simulate an increase in rock-fall volume (Guzzetti et al., 2002). However, by calibrating simulations of the 26 December 2003 and 9 June 2007 rock falls with the actual events, we were able to scale the number of blocks launched from the source area to approximate the volume of potentially unstable rock remaining at the detachment area; in this way, the number of launched blocks serves as a proxy for rock-fall volume. We simulated a range of scenarios, from partial failure of the estimated remaining rock mass (e.g., Fig. 12a) to 
total failure (Fig. 12b). The size of the simulated rock-fall runout zones is directly related to the number of launched blocks, i.e., larger rock "volumes" extend farther beyond the base of the cliff (Fig. 12a,b). Depending on the size of future failures from the detachment area, rock debris from future events has the potential to travel farther beyond the base of the cliff than debris resulting from the 26 December 2003 rock fall; this debris may even travel beyond the rock-fall shadow line (Fig. 12b).

\section{Discussion and conclusions}

Rock falls are common natural occurrences throughout Yosemite Valley, including from Glacier Point. Geologic conditions such as lithology, postglacial weathering of bedrock, joint spacing and orientation, and groundwater infiltration influence the triggering of rock falls in Yosemite Valley. Many of these rock-fall causative factors are present at the Staircase Falls detachment area, a narrow bedrock fin adjacent to Staircase Creek, and contributed to the rock falls in 2003 and 2007. We tentatively attribute a meteorlogical (precipitation and/or frost wedging) triggering mechanism to the 26 December 2003 failure, but do not recognize triggering mechanisms for the smaller failures on 9 June and 26 July 2007 . These latter rock falls illustrate the difficulty of reliably attributing triggering mechanisms to rock falls in Yosemite Valley without detailed monitoring of the detachment area at the time of failure. They also suggest that rock falls from the same detachment area can be triggered by different mechanisms.

Our detailed observations of the 2003 and 2007 Staircase Falls rock falls, mapping of rock-fall debris, field investigations of the detachment area, and numerical modeling of potential future rock falls from the Staircase Falls detachment area indicate that potential rock-fall hazard zones below Staircase Falls extend farther downslope than the mapped base of the talus slope (Wieczorek et al., 1998, 1999). Rock fall hazard zones in this area appear to be better represented by three-dimensional STONE rock-fall simulations than by the shadow angle concept. Additional research into the longer-term frequency of Staircase Falls rock falls, perhaps involving studies of talus volumes, subsurface investigations, and/or cosmogenic exposure dating of talus deposits, is needed to fully characterize the rock-fall hazard in this area.

Acknowledgements. The National Center for Airborne Laser Mapping Airborne (NCALM) at the University of Florida (USA) collected the airborne LiDAR data. We appreciate comments by E. Harp, S. Eaton, M. McSaveney, and an anonymous reviewer that improved the manuscript.

Edited by: T. Glade

Reviewed by: M. McSaveney and another anonymous referee

\section{References}

Agliardi, F. and Crosta, G. B.: High resolution three-dimensional numerical modeling of rockfalls, Int. J. Rock Mech. Min. Sci., 40, 455-471, 2003.

Bahat, D., Grossenbacher, K., and Karasaki, K.: Mechanism of exfoliation joint formation in granitic rocks, Yosemite National Park, J. Struct. Geol., 21, 85-96, 1999.

Barton, N. and Choubey, V.: The shear strength of rock joints in theory and practice, Rock Mechanics, 10, 1-54, 1977.

Bertolo, P. and Wieczorek, G.F.: Calibration of numerical models for small debris flows in Yosemite Valley, California, USA, Nat. Haz. and Earth Sys. Sci., 5, 993-1001, 2005.

Borchers, J. W.: Ground-water resources and water-supply alternatives in the Wawona area of Yosemite National Park, California, US Geol. Surv., Water Res. Invest. Repor,t 95-4229, 1996.

Bursik, M. I., and Gillespie, A. R.: Late Pleistocene glaciation of Mono Basin, California, Quat. Res., 39, 24-35, 1993.

Calkins, F. C., Huber, N. K., and Roller, J. A.: Bedrock geologic map of Yosemite Valley, Yosemite National Park, California, US Geol. Surv. Misc. Invest. Series Map I-1639, 1985.

Chau, K. T., Wong, R. H. C., and Wu, J. J.: Coefficient of restitution and rotation motions of rockfall impacts, Int. J. Rock Mech. and Min. Sc., 39, 69-77, 2002.

Ericson, K., Mignon, P., and Olvmo, M.: Fractures and drainage in the granite mountainous area: A study from the Sierra Nevada, USA, Geomorphology, 64, 97-116, doi:10.1016/j.geomorph.2004.06.003, 2005.

Evans, S. G. and Hungr, O.: The assessment of rockfall hazard at the base of talus slopes, Can. Geotech. J., 30, 620-636, 1993.

Guzzetti, F., Crosta, G., Detti, R., and Agliardi, F.: STONE: A computer program for the three-dimensional simulation of rock-falls, Computers and Geosciences, 28, 1079-1093, 2002.

Guzzetti, F., Reichenbach, P., and Wieczorek, G. F.: Rockfall hazard and risk assessment in the Yosemite Valley, California, USA, Nat. Haz. and Earth Sys. Sci., 3, 491-503, 2003.

Huber, N. K.: The Geologic Story of Yosemite National Park, US Geol. Surv. Bull. 1595, 64, 1987.

Lan, H., and Martin, N.D.: Model calibration for rockfall hazard assessment using LiDAR technology, in: Proceedings, 1st North American Landslide Conference, Vail, Colorado, 3-8 June, 1371-1382, 2007.

LeConte, J. N.: A journal of ramblings through the High Sierras of California, San Francisco, Francis and Valentine, 1875.

Lundquist, J. D. and Cayan, D. R.: Surface temperature patterns in complex terrain: Daily variations and long-term change in the central Sierra Nevada, California, J. Geophys. Res., 112, D11124, doi:10.1029/2006JD007561, 2007.

Martel, S. J.: Effect of topographic curvature on near-surface stresses and application to sheeting joints, Geophys. Res. Lett., 33, L01308, doi:10.1029/2005GL024710, 2006.

Matthes, F. E.: Geologic history of the Yosemite Valley, US Geol. Surv. Prof. Pap. 160, 137, 1930.

Norrish, N. I. and Wyllie, D. C.: Rock slope stability analysis, in: Landslides: Investigation and Mitigation, Washington, D.C., edited by: Turner, A. K. and Schuster, R. L., Transportation Research Board, Special Report 247, 391-425, 1996.

Peck, D. L.: Geologic map of the Yosemite Quadrangle, central Sierra Nevada, California, US Geol. Surv. Geol. Invest. Series Map I-2751, 2002. 
Sharp, R. P.: Sherwin till - Bishop tuff geological relationships, Sierra Nevada, California, Geol. Soc. Am. Bull., 79, 351-364, 1968.

Smith, G. I., Barczak, V. J., Moulton, G. F., and Liddicoat, J. D.: Core km-3, a surface-to-bedrock record of Late Cretaceous sedimentation in Searles Valley, California, US Geol. Surv. Prof. Pap., 1256, 1983.

Twidale, C. R. and Vidale Romani, J. R.: Landforms and Geology of Granite Terrains, London, Taylor and Francis, 350, 2005.

US Geological Survey: Satellite Orthoimage of Yosemite Valley, Yosemite National Park, California, Mariposa County, Experimental Edition, scale 1:24 000, 1986.

Varnes, D. J.: Slope movement types and processes, in: Landslides analysis and control, Washington D.C., edited by: Schuster, R. L., and Krizek, R. J., Transportation Research Board, Special Report 176, 12-33, 1978.

Wahrhaftig, C.: Stepped topography of the southern Sierra Nevada, California: Geol. Soc. Am. Bull., 76, 1165-1190, 1965.

Wieczorek, G. F. and Jäger, S.: Triggering mechanisms and depositional rates of postglacial slope-movement processes in the Yosemite Valley, California, Geomorphology, 15, 17-31, 1996.
Wieczorek, G. F. and Snyder, J. B.: Rock falls from Glacier Point above Camp Curry, Yosemite National Park, California, US Geol. Surv., Open-File Report 99-385, 13, 1999.

Wieczorek, G. F. and Snyder, J. B.: Historical rock falls in Yosemite National Park, US Geol. Surv. Open-File Report 03-491, 2004.

Wieczorek, G. F., Snyder, J. B., Alger, C. S, and Isaacson, K. A.: Rock falls in Yosemite Valley, California, US Geol. Surv. OpenFile Report, 92-387, 38, 1992.

Wieczorek, G. F., Morrissey, M. M., Iovine, G., and Godt, J.: Rockfall hazards in Yosemite Valley, US Geol. Surv. Open-File Report, 98-467, 7, 1998.

Wieczorek, G. F., Morrissey, M. M., Iovine, G., and Godt, J.: Rockfall potential in the Yosemite Valley, California, US Geol. Surv. Open-File Report, 99-578, 7, 1999.

Wieczorek, G. F., Snyder, J. B., Waitt, R. B., Morrissey, M. M., Uhrhammer, R., Harp, E. L., Norris, R. D., Bursik, M. I., and Finewood, L. G.: The unusual air blast and dense sandy cloud triggered by the 10 July 1996, rock fall at Happy Isles, Yosemite National Park, California, Geol. Soc. Am. Bull., 112(1), 75-85, 2000 . 